Матеріали Всеукраїнської науково-практичної конференчії «Актуальні питання діагностики, лікування, раціональної фармакотерапії, диспансеризації та реабілітації в практичі сімейного лікаря"

DOI

\title{
ПОЗИТИВНИЙ ВПЛИВ ШРОТІВ НА ГІПЕРУРИКЕМІЮ ЯК СКЛАДОВИЙ КОМПОНЕНТ МЕТАБОЛІЧНОГО СИНДРОМУ
}

๑С. Л. Гаркуша

КУ «Житомирський обласний медичний консультативно-діагностичний центр»

Цілий ряд проведених досліджень вказують на кореляцію між гіперурикемією (ГУ) та такими складовими частинами метаболічного синдрому (MC) як ожиріння (Ож), артеріальна гіпертензія (АГ), дисліпідемія (ДЛП), гіперглікемія (ГГ), інсулінорезистентність (IP), цукровий діабет (ЦД). ГУ розглядають як один з маркерів і водночас патогенетичних чинників розвитку IP та ССЗ.

Метою даної роботи було дослідження впливу харчування з включенням шротів з насіння розторопші, вівса, гарбуза, пшениці, льону, клітковини із зародків пшениці, гречки з інуліном на рівень ГУ у пацієнтів з МС.

Для дослідження були відібрані 138 осіб з МС (Ож. І-ІІІ ст., ДЛП, АГ, ГГ, ГУ). Досліджувані за раціонами харчування були поділені на 3 групи: I група (35 осіб) - дотримувалася раціону харчування, наближеного до Середземноморської дієти (СД), II група (68 осі6) - раціону харчування з включенням шротів (Шр.), III група (35 осіб) дієти № 9 за Певзнером. При відборі осіб з МС проводили загальноклінічне, інструментальне та лабораторне дослідження вуглеводного, ліпідного та пуринового обмінів, визначали індекс маси тіла.
При складанні меню СД орієнтувалися на Середземноморську піраміду харчування. В її основі - «повільні» вуглеводи, представлені нерафінованими крупами, пастою із твердих сортів пшениці, цільнозерновим хлібом; другий ряд: фрукти, овочі; третій ряд: оливкова олія, горіхи, бобові; четвертий ряд: молочні продукти; на верхівці піраміди - червоне м'ясо.

Особливістю II раціону харчування було обмеження жирів, швидко засвоюваних вуглеводів та поєднання таких продуктів як фрукти, овочі, знежирені молочні продукти з додаванням Шр. в приготовлені страви (вівсяну кашу, салат) або напої (кефір, йогурт або сік). Кількість Шр. у грамах було визначено відповідно до загальноприйнятих рекомендацій, з урахуванням попереднього досвіду застосування рослинних нутрієнтів і ступеня Ож. (35 г на добу при Ож. І ст., 55 г на добу при Ож. ІІ ст., 95 г на добу при Ож. III ст.). Контрольна III група досліджуваних притримувалася дієти № 9 за Певзнером, яка включала підвищений вміст білків при зниженому вживанні жирів і швидкозасвоюваних вуглеводів.

Динамічне зменшення рівня показника сечової кислоти в групах спостереження представлено в таблиці.

Таблиця. Динамічні зміни показника сечової кислоти в групах спостереження

\begin{tabular}{|c|c|c|c|c|}
\hline \multirow{2}{*}{$\begin{array}{c}\text { Показник, } \\
\text { одиниці } \\
\text { виміру }\end{array}$} & $\begin{array}{c}\text { Термін } \\
\text { визначення }\end{array}$ & $\begin{array}{c}\text { I група, раціон харчування } \\
\text { за СД (n=35) }\end{array}$ & $\begin{array}{c}\text { I група, раціон харчування } \\
\text { з включенням Шр. (n=68) }\end{array}$ & $\begin{array}{c}\text { III група, дієта № 9 } \\
\text { за Певзнером (n=35) }\end{array}$ \\
\hline \multirow{2}{*}{$\begin{array}{c}\text { Сечова } \\
\text { кислота, } \\
\text { мкмоль/л }\end{array}$} & Вихідні дані & $440,22 \pm 15,23$ & $451,5 \pm 10,8$ & $460,32 \pm 14,14$ \\
\cline { 2 - 5 } & Через 3 місяці & $415,45 \pm 10,11$ & $354,87 \pm 8,15$ & $425,44 \pm 11,12$ \\
\cline { 2 - 5 } & Через 6 місяців & $365,63 \pm 8,05$ & $315,74 \pm 12,1$ & $390,13 \pm 15,12$ \\
\hline
\end{tabular}

Порівняння рівня сечової кислоти в динаміці засвідчило, що II група вирізнялася найнижчими показниками через 3 та 6 місяців. У І групі спостереження зменшився рівень сечової кислоти через 6 місяців на 16,94 \%, у II групі на 30,1 \%, у контрольній групі рівень сечової кислоти залишався підвищеним.
Таким чином, використання в раціоні харчування шротів з насіння розторопші, вівса, гарбуза, пшениці, льону, гречки з інуліном, клітковини із зародків пшениці позитивно впливає на пуриновий обмін та може бути застосоване у пацієнтів з гіперурикемією, подагрою та метаболічним синдромом. 